\title{
Analisis Kebutuhan Bimbingan Pribadi Sosial Berbasis Context, Experience, and Reality (CER) untuk Meningkatkan Karakter Kebajikan Siswa Sekolah Menengah Pertama
}

\author{
IM Hambali* \\ Jurusan Bimbingan dan Konseling, Fakultas Ilmu Pendidikan, Universitas Negeri Malang \\ Jl. Semarang No. 5, Malang, Jawa Timur, Indonesia, 65145 \\ *Penulis koresponden, e-mail: im.hambali.fip@um.ac.id
}

Artikel diterima: 20 Juli 2018; direvisi: 6 Maret 2019; disetujui: 26 Maret 2019

\begin{abstract}
The general objective of the study is to describe the needs of junior high school counselor toward CER-based socio-personal guidance service in order to improve the virtue of junior high school students. During the conduct of the study, the researcher implemented the survey design in order to attain the description data. The results of the study show that the counselors need CER-based media for improving the virtue of the junior high school students. Therefore, the counselor should search, find, create and even design the CER-based service media.
\end{abstract}

Keywords: CER; socio-personal guidance service; junior high school

\begin{abstract}
Abstrak: Tujuan umum penelitian ini adalah mengetahui deskripsi kebutuhan konselor sekolah menengah pertama (SMP) akan media layanan bimbingan pribadi sosial berbasis $C E R$ untuk meningkatkan karakter kebajikan siswa SMP. Penelitian dilakukan dengan menggunakan desain survei untuk mendapatkan data deskriptif. Hasil penelitian menunjukkan bahwa konselor membutuhkan media berbasis $C E R$ untuk meningkatkan karakter kebajikan siswa SMP. Oleh karena itu, konselor harus mencari, menemukan, dan berkreasi, bahkan membuat media layanan berbasis $C E R$.
\end{abstract}

Kata kunci: $C E R$; bimbingan pribadi sosial; SMP

\section{PENDAHULUAN}

Layanan bimbingan pribadi sosial perlu diberikan kepada semua siswa SMP untuk membekali siswa dengan kemampuan berpikir logis/analitis; sistematis; kritis; dan kreatif serta kemampuan bekerja sama dalam proses pembentukan karakter kebajikan. Kompetensi tersebut diperlukan agar siswa memiliki kemampuan memperoleh, mengolah, dan memanfaatkan informasi serta pengalaman untuk bertahan hidup pada keadaan yang selalu berubah, tidak pasti, dan kompetitif. Layanan bimbingan pribadi sosial adalah salah satu layanan yang sangat dibutuhkan oleh siswa, namun pada kenyataannya justru ditakuti oleh siswa karena dapat dianggap sebagai layanan untuk siswa bermasalah (Prasetiyono, 2015). Hal ini membuat siswa menjadi malas untuk mengikuti bimbingan pribadi sosial seperti yang terjadi pada sebagian siswa SMP.

Berdasarkan pengamatan, proses layanan bimbingan pribadi sosial pada siswa SMP menunjukkan belum ada peningkatan aktivitas, baik dari siswa maupun konselor. Hal tersebut terlihat ketika proses bimbingan pribadi sosial, tidak ada satupun siswa yang menjawab pertanyaan reflektif konselor, tidak ada siswa yang maju untuk mengerjakan tugas bimbingan di depan kelas. Pada saat kegiatan inti layanan, konselor masih mendominasi layanan. Selain itu, konselor juga kurang memanfaatkan media dalam

Cara mengutip: Hambali, I. (2019). Analisis Kebutuhan Bimbingan Pribadi-Sosial Berbasis Context, Experience, and Reality (CER) untuk Meningkatkan Karakter Kebajikan Siswa Sekolah Menengah Pertama. Jurnal Kajian Bimbingan dan Konseling, 4(1), 37-45. https://doi. org/10.17977/um001v4i12019p037 
proses layanan bimbingan pribadi sosial, tidak ada interaksi multi arah antara siswa dengan konselor dan siswa dengan siswa. Kurangnya interaksi tersebut mengakibatkan siswa malas untuk menanyakan solusi tentang kesulitan yang sedang dihadapi dalam proses bimbingan.

Ruang lingkup layanan bimbingan pribadi sosial pada satuan pendidikan SMP meliputi: (1) semangat hidup; (2) komitmen dan kejujuran; (3) pengolahan data faktual dan pengalaman. Selain itu, karakter yang dikembangkan meliputi 4 K (kreatif; kompetitif; komunikatif dan kerjasama). Sedangkan materi layanan bimbingan pribadi sosial jenjang SMP meliputi semangat hidup dalam pemecahan setiap masalah yang akan muncul akibat perubahan sikap dan perilaku, yang meliputi sikap: jujur; komitmen; mampu mengutarakan pendapat; dan kedalaman dalam setiap pemecahan masalah. Sehubungan dengan hal tersebut, layanan bimbingan pribadi sosial haruslah dirancang sistematis dan komprehensif.

Dalam pelayanan bimbingan dan konseling (BK) pribadi sosial, konselor memfasilitasi siswa untuk memahami konsep perkembangan pribadi sosial. Siswa dibimbing untuk berpikir konkret; kontekstual; dan abstrak. Untuk itu perlu dikembangkan media dengan konsep CER. Apabila siswa tidak menguasai konsep pengalaman dan konteks ini, maka akan sulit memahami kehidupan yang produktif, dalam arti hidup yang dapat membuahkan kebahagiaan; keharmonisan; semangat dan optimis menatap masa depan. Kemampuan memahami pengalaman dan konteks meliputi menelaah konteks dan pemaknaan realita kehidupan yang telah dijalani dalam kehidupan sehari-hari.

Permasalahan utama dalam proses layanan bimbingan pribadi sosial ialah belum jelasnya sentuhan nilai-nilai karakter kebajikan yang harus dimasukkan dalam proses layanan. Di sisi lain, kurikulum 2013 mengamanatkan adanya proses layanan berbasis aktivitas dan berbasis karakter kebajikan. Untuk layanan berbasis aktivitas, sejumlah model layanan telah banyak ditawarkan, terutama model layanan kooperatif dan saintifik. Namun, model layanan yang berbasis pendidikan karakter kebajikan belum banyak dijumpai bahkan bisa dikatakan belum ada.

Layanan bimbingan pribadi sosial berbasis karakter kebajikan ialah layanan yang mampu mengintegrasikan nilai-nilai karakter kebajikan ke dalam proses-proses yang bermuatan materi bimbingan pribadi sosial. Apakah proses tersebut sudah berjalan di SMP dengan baik? Jawabannya tidaklah mudah, namun hasil wawancara dengan konselor SMP, menunjukkan beberapa fakta: (1) konselor belum banyak berkreasi mengembangkan media secara independen; (2) konselor mengharapkan hasil pengembangan media maupun model dari para ahli disosialisasikan kepada mereka; (3) konselor enggan mengembangkan sebuah proses inovasi model layanan yang berbasis karakter kebajikan. Oleh karena itu, permasalahan yang harus segera dipecahkan ialah mewujudkan model layanan yang dalam prosesnya dapat menstimulasi siswa ke pemahaman dan perubahan sikap menuju karakter mulia (kebajikan). Model layanan $C E R$, merupakan salah model yang diharapkan. Model $C E R$ ialah sebuah model layanan yang dirancang secara khusus untuk memasukkan aspek nilai karakter kebajikan sebagai muatan integral dengan materi inti yang menjadi tema layanan. Model $C E R$ memiliki tiga elemen yang saling berhubungan secara visual, seperti yang disajikan pada gambar 1.

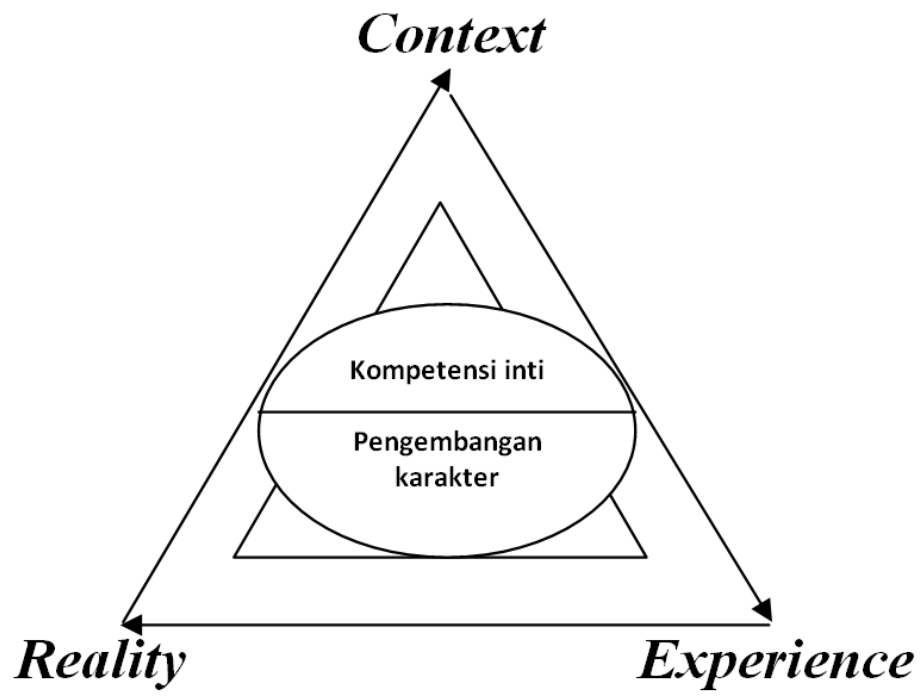

Gambar 1. Siklus Model Layanan CER 
Context adalah kenyataan dan dapat disiasati dengan cara memberikan contoh kepada siswa dalam kehidupan nyata. Contoh tersebut selanjutnya dijadikan sebagai bahan yang dapat diasosiasikan oleh siswa ke dalam pengalaman mereka. Contoh-contoh yang diberikan boleh sama antara siswa satu dengan siswa lainnya. Dengan demikian, konselor dapat mempersiapkan beberapa sumber dan contoh pengalaman yang relevan dengan materi yang hendak diajarkan. Sedangkan experience merupakan proses yang dirancang secara sistematis melalui lembar kerja siswa yang di dalamnya mengandung pekerjaan dan aktivitas yang berbasis karakter kebajikan.

Experience adalah proses dimana konselor memberi stimulasi tindakan yang harus dilaksanakan oleh siswa berupa tugas-tugas ataupun lembar kerja siswa. Pekerjaan tersebut dapat dikerjakan oleh siswa dalam kelas maupun di luar kelas, namun tetap mengacu kepada tugas yang diberikan pada saat berlangsung layanan di kelas. Dalam elemen ini, konselor mengawal dan mendampingi proses asosiasi antara materi bimbingan pribadi sosial yang diajarkan dengan pengalaman siswa.

Reality adalah proses yang mana konselor melakukan kegiatan seperti kegiatan context, bedanya pada proses reality kehidupan nyata yang dijadikan dalam pemberian tugas dan lembar kerja disesuaikan dengan kondisi nyata masing-masing siswa. Jadi, setiap siswa memiliki asosiasi reality yang berbedabeda. Keberbedaan inilah yang selanjutnya oleh konselor dapat dijadikan sebagai infusiasi karakter kebajikan dalam wilayah asosiasi yang dilakukan oleh siswa saat mengerjakan tugas dan lembar kerja.

Kurikulum 2013 dirancang secara khusus sebagai strategi untuk membawa pelajar Indonesia ke dalam suatu perkembangan kepribadian yang komprehensif dan bermakna luas. Layanan yang dikembangkan harus mengandung aktivitas dan berbasis karakter kebajikan. Dengan beberapa uraian diatas, pengembangan Model layanan CER diasumsikan dapat digunakan sebagai solusi bagi konselor untuk mengkompilasi pendidikan yang berorientasi kepada materi dan karakter kebajikan sekaligus.

Belajar merupakan perubahan perilaku yang dihasilkan dari pengalaman (De Houwer dkk., 2013). Barron dkk. (2015) menyatakan bahwa belajar pada umumnya didefinisikan sebagai perubahan perilaku. Dari kedua pendapat tersebut, tampak bahwa belajar ditandai dengan adanya perubahan tingkah laku sebagai hasil pengalaman yang bersifat tahan lama dan bukan sebagai hasil dari proses pertumbuhan. Dengan demikian, perubahan tingkah laku sebagai hasil belajar ditandai dengan ciri-ciri: (1) di sengaja dan bertujuan; (2) tahan lama; (3) bukan karena kebetulan; dan (4) bukan karena kematangan dan pertumbuhan. Apabila setelah belajar tidak ada perubahan dalam diri manusia, maka tidak dapat dikatakan bahwa padanya telah berlangsung proses belajar.

Belajar merupakan kata dasar "layanan", dalam arti sempit diartikan sebagai proses atau cara yang dilakukan seseorang dapat melakukan kegiatan belajar. Menurut Mulyono (2001) aktivitas artinya "kegiatan atau keaktifan", jadi segala sesuatu yang dilakukan atau kegiatan-kegiatan yang terjadi baik fisik maupun non-fisik merupakan suatu aktivitas. Aktivitas siswa selama proses belajar mengajar merupakan salah satu indikator adanya keinginan untuk belajar. Jihad (2008) menyatakan bahwa bimbingan pribadi sosial diartikan sebagai telaah tentang pola dan hubungan suatu jalan atau pola berpikir, seni, bahasa dan alat. Bimbingan pribadi sosial berarti bernalar. Jadi, belajar dalam bimbingan pribadi sosial berhubungan dengan penalaran.

Karakter kebajikan adalah kemampuan seseorang yang menonjol di bidang pribadi yang mencakup aspek: (1) semangat hidup; (2) komitmen dan kejujuran; dan (3) pengolahan data faktual serta pengalaman yang diperoleh dalam berinteraksi dengan lingkungannya. Dalam hal ini, bimbingan pribadi sosial berfungsi sebagai fasilitasi lingkungan, dengan demikian karakter kebajikan dalam bimbingan pribadi sosial adalah hasil yang telah dicapai siswa setelah mengikuti proses layanan bimbingan pribadi sosial. Mengacu pada uraian di atas, tujuan penelitian ini adalah mendeskripsikan kebutuhan konselor SMP terhadap media bimbingan pribadi sosial berbasis CER yang dapat meningkatkan karakter kebajikan siswa SMP.

\section{METODE}

Penelitian ini termasuk penelitian deskriptif kuantitatif. Untuk tahap pertama penelitian ini, dilakukan survei deskriptif yang bertujuan mendeskripsikan sejauh mana kebutuhan konselor sekolah akan model yang hendak dikembangkan. Oleh karena penelitian ini merupakan penelitian tahap awal yang berupa survei kondisi kebutuhan dan realitas fasilitas bimbingan yang ada di sekolah, maka penelitian ini belum menghasilkan produk. 
Populasi penelitian ini ialah konselor SMP di kota Malang. Sampel diambil secara acak di setiap SMP, jumlah sampel sebanyak 51 konselor. Data dikumpulkan menggunakan angket yang berisi daftar pertanyaan tentang konteks, pengalaman dan kondisi realita. Data dianalisis secara deskriptif dan ditafsirkan secara dialogis. Hasil penafsiran disajikan dalam bentuk diagram batang, yang selanjutnya didiskusikan. Hal ini bertujuan untuk membandingkan antara kenyataan dan seharusnya, antara konteks dan empiris, serta antara hasil penelitian sebelumnya yang dikatakan sebagai sumber data meta analisis.

\section{HASIL}

\section{Deskripsi Data Konteks}

Data konteks (context) adalah informasi yang disajikan dalam bentuk tabel dan uraian serta penjelasan, analisis dan argumentasi yang menyangkut kondisi-kondisi serta alasan yang relevan dengan materi dan tema layanan bimbingan. Data kuantitatif terkait konteks disajikan pada gambar 2 dan tabel 1. Media (dalam analisis input-proses-output) merupakan bagian dari input yang sangat menentukan hasil atau output. Tingkat capaian layanan bimbingan dan konseling dapat diestimasi dari ketersediaan media yang mampu dipenuhi dengan baik. 41 konselor atau $80 \%$ dari 51 konselor menanggapi pernyataan: "Setiap ingin menggunakan media layanan, konselor harus berkreasi mencari, menemukan, bahkan membuat media sendiri" dengan jawaban "ya". Data tersebut menunjukkan bahwa media yang dibutuhkan sementara ini dapat dikatakan belum ada atau belum tersedia di sekolah, dan pengembangan media sangat diharapkan oleh konselor. Keterbatasan waktu yang dimiliki oleh konselor menjadikan mereka sulit menyediakan waktu untuk membuat dan atau menciptakan media yang memadai.

\section{Deskripsi Data Pengalaman}

Data pengalaman (experience) adalah informasi yang disajikan dalam bentuk tabel dan uraian serta penjelasan, analisis serta argumentasi yang menyangkut pengalaman atau situasi dan kondisi yang diciptakan untuk mendatangkan pengalaman yang relevan dengan materi dan tema layanan bimbingan. Data kuantitatif terkait pengalaman disajikan pada gambar 3 dan tabel 2. Pada saat konselor dimintai penjelasan mengenai pernyataan: "Pengalaman siswa yang didapat dari kehidupan nyata di rumah selalu dikomunikasikan kepada konselor" Sebanyak 65\% konselor menjawab "ya", mereka mengungkapkan bahwa siswa tidak banyak memberi informasi mengenai pengalaman tidak menyenangkan pada saat di rumah atau lingkungan keluarga.

Untuk memenuhi kualitas data sebagai dasar konselor dalam memberikan layanan bimbingan, konselor tidak jarang mencari data pengalaman tersebut dengan menanyakan kepada siswa. Apakah kemudian siswa memberi data pengalaman tidak menyenangkan di rumah yang cukup memadai? sebagian menjawab tidak, hanya sebagian kecil konselor yang menjawab "ya" pada pernyataan: "Siswa selalu memberi informasi yang memuaskan jika dimintai keterangan tentang pengalaman mereka di rumah".

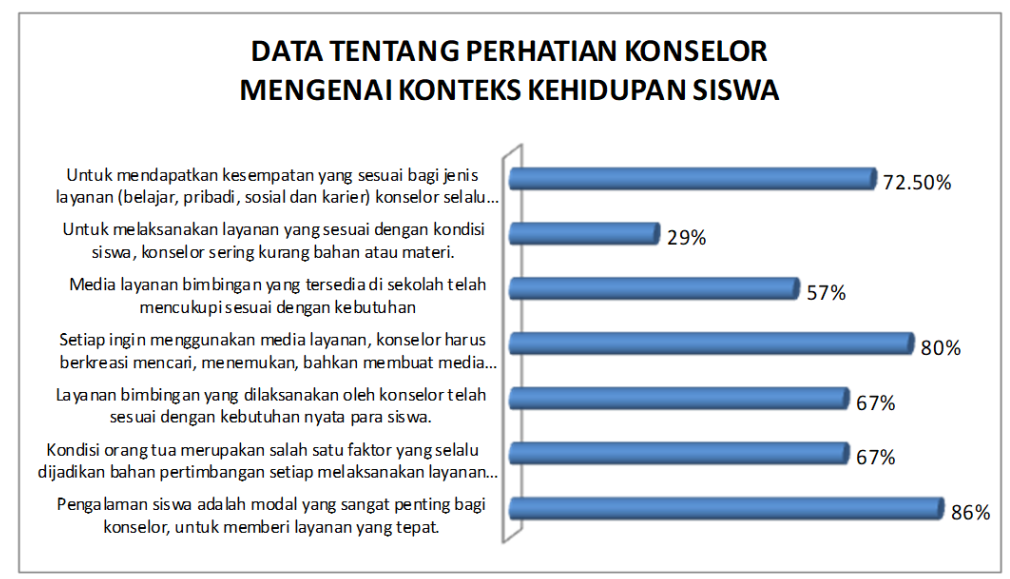

Gambar 2. Diagram Perhatian Konselor Terhadap Konteks Kehidupan Siswa 


\section{Tabel 1. Data Tentang Konteks}

\begin{tabular}{|c|c|c|c|c|c|c|}
\hline \multirow{3}{*}{ No. } & \multirow{3}{*}{ Pernyataan } & \multicolumn{4}{|c|}{ Jawaban } & \multirow{3}{*}{ Total } \\
\hline & & \multicolumn{2}{|l|}{ Ya } & \multicolumn{2}{|c|}{ Tidak } & \\
\hline & & Jumlah & $\%$ & Jumlah & $\%$ & \\
\hline 1 & $\begin{array}{l}\text { Untuk mendapatkan kesempatan yang sesuai bagi jenis } \\
\text { layanan (belajar; pribadi; sosial dan karier) konselor selalu } \\
\text { memiliki waktu cukup untuknya }\end{array}$ & 37 & 72,5 & 14 & 27 & 51 \\
\hline 2 & $\begin{array}{l}\text { Untuk melaksanakan layanan yang sesuai dengan kondisi } \\
\text { siswa, konselor sering kurang bahan atau materi }\end{array}$ & 15 & 29 & 36 & 71 & 51 \\
\hline 3 & $\begin{array}{l}\text { Media layanan bimbingan yang tersedia di sekolah telah } \\
\text { mencukupi sesuai dengan kebutuhan }\end{array}$ & 29 & 57 & 22 & 43 & 51 \\
\hline 4 & $\begin{array}{l}\text { Setiap ingin menggunakan media layanan, konselor harus } \\
\text { berkreasi mencari, menemukan, bahkan membuat media } \\
\text { sendiri }\end{array}$ & 41 & 80 & 10 & 20 & 51 \\
\hline 5 & $\begin{array}{l}\text { Layanan bimbingan yang dilaksanakan oleh konselor telah } \\
\text { sesuai dengan kebutuhan nyata para siswa }\end{array}$ & 34 & 67 & 17 & 33 & 51 \\
\hline 6 & $\begin{array}{l}\text { Kondisi orangtua merupakan salah satu faktor yang selalu } \\
\text { dijadikan bahan pertimbangan setiap melaksanakan layanan } \\
\text { bimbingan di sekolah }\end{array}$ & 34 & 67 & 17 & 33 & 51 \\
\hline 7 & $\begin{array}{l}\text { Pengalaman siswa adalah modal yang sangat penting bagi } \\
\text { konselor, untuk memberi layanan yang tepat }\end{array}$ & 44 & 86 & 7 & 14 & 51 \\
\hline
\end{tabular}

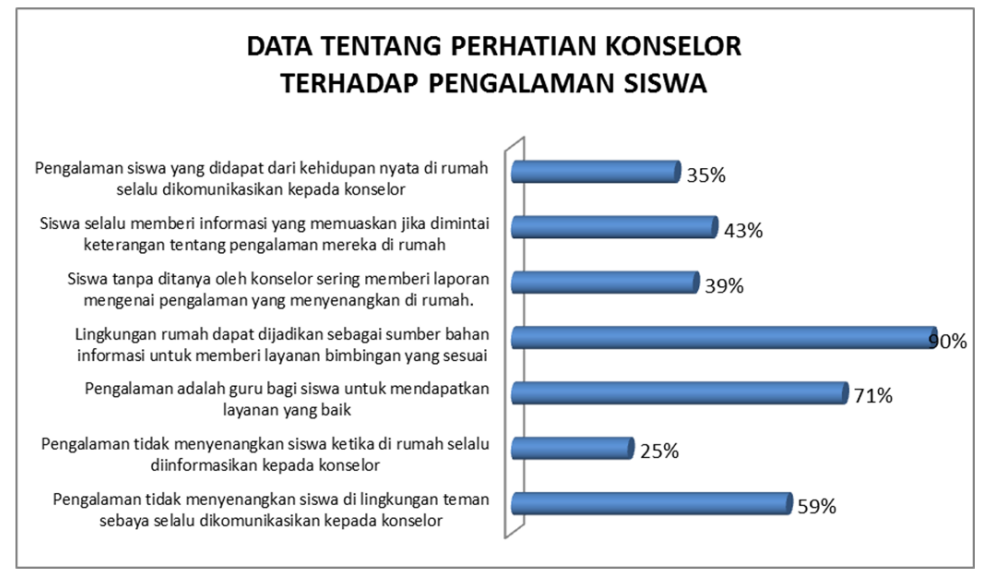

\section{Gambar 3. Diagram Perhatian Konselor Terhadap Pengalaman Siswa}

Tabel 2. Data Tentang Pengalaman

\begin{tabular}{|c|c|c|c|c|c|c|}
\hline \multirow{3}{*}{ No. } & \multirow{3}{*}{ Pernyataan } & \multicolumn{4}{|c|}{ Jawaban } & \multirow{3}{*}{ Total } \\
\hline & & \multicolumn{2}{|l|}{ Ya } & \multicolumn{2}{|c|}{ Tidak } & \\
\hline & & Jumlah & $\%$ & Jumlah & $\%$ & \\
\hline 1 & $\begin{array}{l}\text { Pengalaman siswa yang didapat dari kehidupan nyata di rumah } \\
\text { selalu dikomunikasikan kepada konselor }\end{array}$ & 18 & 35 & 33 & 65 & 51 \\
\hline 2 & $\begin{array}{l}\text { Siswa selalu memberi informasi yang memuaskan jika } \\
\text { dimintai keterangan tentang pengalaman mereka di rumah }\end{array}$ & 22 & 43 & 29 & 57 & 51 \\
\hline 3 & $\begin{array}{l}\text { Siswa tanpa ditanya oleh konselor sering memberi laporan } \\
\text { mengenai pengalaman yang menyenangkan di rumah }\end{array}$ & 20 & 39 & 31 & 61 & 51 \\
\hline 4 & $\begin{array}{l}\text { Lingkungan rumah dapat dijadikan sebagai sumber bahan } \\
\text { informasi untuk memberi layanan bimbingan yang sesuai }\end{array}$ & 46 & 90 & 5 & 0,9 & 51 \\
\hline 5 & $\begin{array}{l}\text { Pengalaman adalah guru bagi siswa untuk mendapatkan } \\
\text { layanan yang baik }\end{array}$ & 36 & 71 & 5 & 0,9 & 51 \\
\hline 6 & $\begin{array}{l}\text { Pengalaman tidak menyenangkan siswa ketika di rumah selalu } \\
\text { diinformasikan kepada konselor }\end{array}$ & 13 & 25 & 38 & 75 & 51 \\
\hline 7 & $\begin{array}{l}\text { Pengalaman tidak menyenangkan siswa di lingkungan teman } \\
\text { sebaya selalu dikomunikasikan kepada konselor }\end{array}$ & 30 & 59 & 21 & 41 & 51 \\
\hline
\end{tabular}


Bagaimana jika siswa tidak memberikan penjelasan perihal pengalaman mereka di lingkungan rumah? Kenyataannya, 20 dari 51 konselor atau 39\% menjawab "ya" pada pernyataan: "Siswa tanpa ditanya oleh konselor sering memberi laporan mengenai pengalaman yang menyenangkan di rumah". Dengan demikian, tidak ada kemungkinan lain kecuali harus segera dikembangkan suatu model layanan bimbingan yang memungkinan untuk hal tersebut. 13 dari 51 konselor atau sekitar 25\% menyatakan: "Pengalaman tidak menyenangkan siswa ketika di rumah selalu diinformasikan kepada konselor". Data tersebut memberi penguatan terhadap data sebelumnya, yang menunjukkan sulitnya mendapatkan informasi mengenai pengalaman siswa yang kurang menyenangkan. Jika hal ini dibiarkan, maka pelaksanaan layanan bimbingan tidak menjadi lebih baik, bahkan dapat terjadi penurunan kualitas.

\section{Deskripsi Data Kenyataan}

Data kenyataan (reality) adalah informasi yang disajikan dalam bentuk tabel dan uraian serta penjelasan, analisis, juga argumentasi menyangkut realitas siswa (baik di rumah, di lingkungan teman sebaya, dan di sekolah) yang relevan dengan materi dan tema layanan bimbingan. Data kuantitatif secara rinci disajikan pada gambar 4 dan tabel 3.

Pernyataan terkait realitas yang diajukan kepada konselor ialah: "Apapun yang dilakukan oleh siswa dalam lingkungan keluarga selalu dikomunikasikan siswa kepada konselor". Dari pernyataan tersebut, hanya 13 dari 51 atau 25\% konselor yang menjawab "ya". Data tersebut memberi pengertian bahwa sebagian besar siswa (75\%) tidak pernah memberi penjelasan perihal kehidupan nyata di rumah kepada konselor.

Dalam kesempatan yang sama, hanya 14 dari 51 konselor atau 27\% yang menjawab "ya" pada pernyataan: "Setiap ada kegiatan siswa di rumah yang dirasakan kurang menyenangkan selalu dikemukakan olehnya kepada konselor". Data ini menguatkan data sebelumnya, bahwa pengalaman siswa di rumah yang kurang menyenangkan tidak sampai pada konselor. Kemungkinan dampak negatif yang akan timbul adalah terjadinya pengalihan pengalaman yang dirasa menyakitkan ke sebuah kehidupan dan perilaku yang tidak menguntungkan bagi kehidupan siswa di masa mendatang. Kemungkinan itu diperkuat jika lingkungan teman sebaya siswa juga memberi pengaruh negatif dengan tindakan-tindakan yang kurang terpuji akibat kekecewaan di lingkungan rumah tangga.

Lantas apa yang diperlukan oleh konselor sehubungan dengan kenyataan ini? Konselor sebenarnya akan lebih mudah menjalankan fungsinya sebagai pendamping perkembangan siswa jika telah tersedia sebuah model layanan yang memungkinkan kendala tersumbatnya informasi telah diatasi. Modelmodel yang tersedia apakah sudah memadai? Jawaban dari pertanyaan tersebut dapat dicermati bahwa sebagian kecil konselor, yakni 20 dari 51 atau 39\% orang yang dimintai keterangan menjawab "ya" pada pernyataan: "Konselor sangatlah mudah mendapat informasi kehidupan sehari-hari siswa di rumah sebagai bahan dalam setiap memberikan layanan".

Cukup kuat data yang menunjukkan bahwa informasi perihal pengalaman realitas dalam kehidupan sehari-hari siswa tidaklah sampai ke konselor. Kenyataan tersebut menuntut jawaban yang harus diberikan oleh para ahli bimbingan dan konseling untuk segera mewujudkan dan mengembangkan

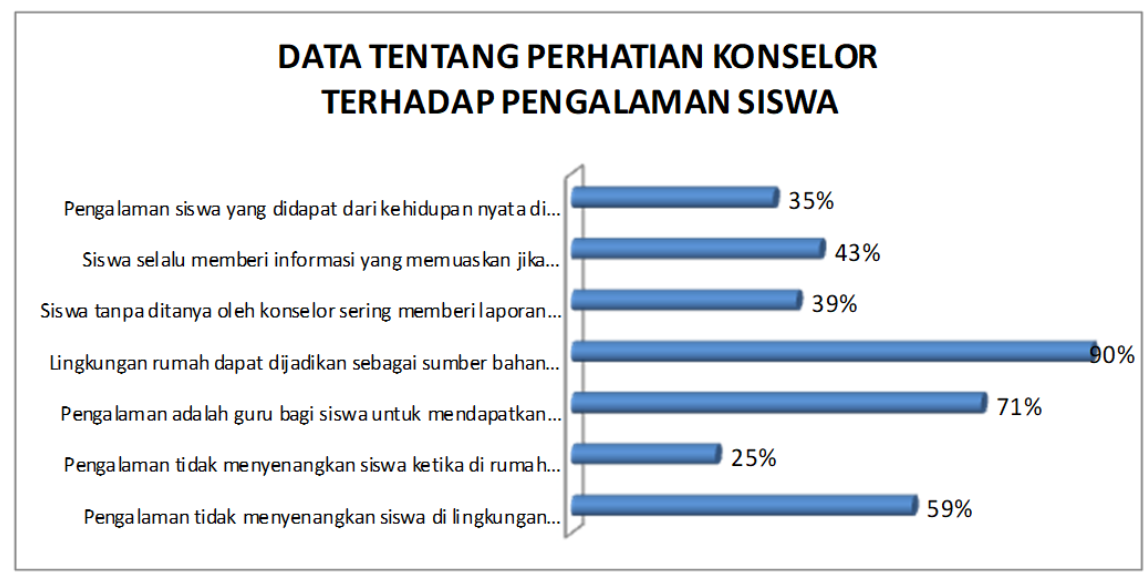

Gambar 4. Diagram Perhatian Konselor Terhadap Kehidupan Nyata Siswa 


\begin{tabular}{|c|c|c|c|c|c|c|}
\hline \multirow{3}{*}{ No. } & \multirow{3}{*}{ Pernyataan } & \multicolumn{4}{|c|}{ Jawaban } & \multirow{3}{*}{ Tota } \\
\hline & & \multicolumn{2}{|c|}{ Ya } & \multicolumn{2}{|c|}{ Tidak } & \\
\hline & & Jumlah & $\%$ & Jumlah & $\%$ & \\
\hline 1 & $\begin{array}{l}\text { Untuk memulai layanan, konselor selalu melihat kondisi riil } \\
\text { siswa di lingkungan keluarga }\end{array}$ & 40 & 78 & 11 & 22 & 51 \\
\hline 2 & $\begin{array}{l}\text { Kondisi riil siswa di lingkungan keluarga penting menjadi } \\
\text { bahan pertimbangan dalam menjalankan setiap layanan }\end{array}$ & 49 & 96 & 2 & 0,4 & 51 \\
\hline 3 & $\begin{array}{l}\text { Kondisi riil siswa di lingkungan keluarga tercermin dalam } \\
\text { setiap tingkah laku siswa di sekolah }\end{array}$ & 37 & 72,5 & 14 & 27 & 51 \\
\hline 4 & $\begin{array}{l}\text { Informasi mengenai kehidupan sehari-hari siswa secara mudah } \\
\text { dapat diperoleh dari informasi siswa }\end{array}$ & 33 & 65 & 18 & 35 & 51 \\
\hline 5 & $\begin{array}{l}\text { Apapun yang dilakukan oleh siswa dalam lingkungan keluarga } \\
\text { selalu dikomunikasikan siswa kepada konselor }\end{array}$ & 13 & 25 & 38 & 75 & 51 \\
\hline 6 & $\begin{array}{l}\text { Setiap ada kegiatan siswa di rumah yang dirasakan kurang } \\
\text { menyenangkan selalu dikemukakan olehnya kepada konselor }\end{array}$ & 14 & 27 & 37 & 72,5 & 51 \\
\hline 7 & $\begin{array}{l}\text { Konselor sangatlah mudah mendapat informasi kehidupan } \\
\text { sehari-hari siswa di rumah sebagai bahan dalam setiap } \\
\text { memberikan layanan }\end{array}$ & 20 & 39 & 31 & 61 & 51 \\
\hline
\end{tabular}

model layanan yang secara khusus dirancangbangun sesuai dengan kebutuhan seperti halnya ditemukan di atas. Dari beberapa data diatas dapat dimengerti jika model $C E R$ yang hendak dikembangkan ini sangat ditunggu, relevan, dan urgen.

\section{PEMBAHASAN}

Media pada dasarnya merupakan seperangkat alat pendukung layanan (Luo, 2018; Yamamoto dkk., 2016). Model CER merupakan model yang sangat memerlukan media. Pengembangan model $C E R$ menjadi sangat penting guna mendukung pelayanan bimbingan bermedia multi fungsi yang dapat menjembatani konselor menuju capaian layanan yang baik. Untuk context dan experience, konselor dapat memberi contoh-contoh yang pada umumnya terjadi di lingkungan sekitar, dimana siswa yang satu dengan yang lainnya boleh memahami perihal pengalaman yang sama. Sedangkan untuk reality, konselor harus membawa masing-masing siswa ke dalam realitas dan pengalaman nyata mereka sendirisendiri yang akan berbeda antara siswa satu dengan yang lainnya. Membawa siswa dalam kenyataan dalam belajar mampu meningkatkan pemahaman siswa mengenai hal yang dipelajari (Betts dkk., 2017; Brand dkk., 2013; Kobayashi dkk., 2017). Dalam proses ini konselor mulai menunjukkan keterkaitan antara materi dengan nilai karakter kebajikan yang harus diinternalisasi oleh masing-masing siswa. Ketersediaan model CER ini menjadi penting bagi keberlangsung tugas-tugas layanan konselor, sekaligus meningkatkan fungsi dan kinerja dalam sebagian tema yang selama ini kurang memadai.

Pengalaman siswa, baik di rumah, di sekolah, maupun di lingkungan teman sebaya merupakan bagian kehidupan siswa yang memiliki kontribusi kuat terhadap perkembangan karakter (Leung \& Shek, 2013; Omar dkk., 2017; Wilodati, 2016). Karakter dibentuk dari sejumlah pengetahuan dan pengalaman (Crescentini dkk., 2015; Cuyjet \& Duncan, 2013; Hsiao dkk., 2015; Li \& Pollatsek, 2011). Semakin baik pengalaman, dalam arti pengalaman yang dapat mendukung perkembangan karakter kebajikan, maka kemungkinan karakter yang terbentuk menjadi baik sangatlah tinggi. Media komunikasi adalah media yang sangat penting untuk menjadikan layanan bimbingan dapat berkualitas. Jika media komunikasi tidak membuahkan hasil yang memadai, maka konselor harus menyusun media yang dapat mengarahkan siswa untuk dapat bekerjasama mencapai perkembangan yang baik dan karakter kebajikan dapat berkembang tanpa ada hambatan.

Realitas kehidupan adalah suatu sumber pengalaman yang paling otentik, dan bersifat individual. Perbedaan pribadi siswa satu dengan yang lainnya terutama bersumber dari perbedaan realitas kehidupan mereka masing-masing. Dalam hal ini, keterlibatan fungsional realitas siswa dapat menjadikan layanan 
tepat sasaran dan dapat mengurangi kesalahan di dalam pengambilan keputusan oleh siswa. Namun, seberapapun pentingnya sebuah informasi mengenai realitas kehidupan siswa, realitas tersebut adalah hak milik pribadi siswa.

Kenyataan ini juga menjadi sumber kurang memadainya pelayanan yang diberikan oleh konselor, karena kehidupan nyata siswa ketika di lingkungan rumah dapat memberi inspirasi tema dan strategi yang dapat dipilih sebagai upaya peningkatan kualitas karakter kebajikan siswa. Oleh karena itu, bagaimanapun konselor harus dapat menemukan cara agar siswa dapat memberikan informasi yang cukup memadai mengenai kehidupan mereka sehari-hari. Terlebih jika pengalaman nyata siswa di lingkungan rumah bersifat kurang menyenangkan atau bahkan menyakitkan. Pengalaman demikian jika tidak dikomunikasikan kepada pihak yang berkompeten, dan dapat memberi fasilitas pendampingan yang mengarah pada perkembangan dan terbentuknya karakter kebajikan yang baik, maka kenyataan itu akan menjadi mubadzir. Oleh sebab itu, upaya-upaya para ahli bimbingan dan konseling untuk menciptakan suatu strategi yang memadukan dan memandu pengalaman realitas siswa ketika di rumah sangatlah penting dan mendesak adanya.

\section{SIMPULAN}

Dari penelilitian ini, dapat disimpulkan bahwa menurut konselor, layanan bimbingan pribadi sosial berbasis $C E R$ sangat dibutuhkan oleh siswa dan konselor, namun belum ada media berbasis $C E R$ yang memadai. Terkait dengan hal tersebut, konselor disarankan: (1) mengembangkan sebuah model layanan bimbingan pribadi sosial berbasis $C E R$ dan melacak sumber-sumber yang ada untuk mendapatkan model serta media layanan bimbingan pribadi sosial yang relevan untuk pengembangan karakter kebajikan.

\section{DAFTAR RUJUKAN}

Barron, A. B., Hebets, E. A., Cleland, T. A., Fitzpatrick, C. L., Hauber, M. E., \& Stevens, J. R. (2015). Embracing Multiple Definitions of Learning. Trends in Neurosciences, 38(7), 405-407.

Betts, P., McLarty, M., \& Dickson, K. (2017). An Action Research Project by Teacher Candidates and Their Instructor into using Math Inquiry: Learning about Relations between Theory and Practice. Networks: An Online Journal for Teacher Research, 19(1). https://doi.org/10.4148/2470-6353.1011

Brand, B., Valent, A., \& Browning, A. (2013). How Career and Technical Education Can Help Students Be College and Career Ready: A Primer. College and Career Readiness and Success Center.

Crescentini, C., Matiz, A., \& Fabbro, F. (2015). Improving Personality/Character Traits in Individuals with Alcohol Dependence: The Influence of Mindfulness-Oriented Meditation. Journal of Addictive Diseases, 34(1), 7587. https://doi.org/10.1080/10550887.2014.991657

Cuyjet, M. J., \& Duncan, A. D. (2013). The Impact of Cultural Competence on the Moral Development of Student Affairs Professionals. Journal of College and Character, 14(4), 301-310. https://doi.org/10.1515/jcc-20130039

De Houwer, J., Barnes-Holmes, D., \& Moors, A. (2013). What is Learning? On The Nature and Merits of A Functional Definition of Learning. Psychonomic Bulletin \& Review, 20(4), 631-642.

Hsiao, H.-S., Chang, C.-S., Chen, C.-J., Wu, C.-H., \& Lin, C.-Y. (2015). The Influence of Chinese Character Handwriting Diagnosis and Remedial Instruction System on Learners of Chinese as A Foreign Language. Computer Assisted Language Learning, 28(4), 306-324. https://doi.org/10.1080/09588221.2013.818562

Jihad, A. (2008). Evaluasi Pembelajaran. Multi Pressindo.

Kobayashi, S., Berge, M., Grout, B. W. W., \& Rump, C. Ø. (2017). Experiencing Variation: Learning Opportunities in Doctoral Supervision. Instructional Science, 45(6), 805-826. https://doi.org/10.1007/s11251-017-9422-4

Leung, J. T. Y., \& Shek, D. T. L. (2013). Are Family Processes Related to Achievement Motivation of Chinese Adolescents Experiencing Economic Disadvantage in Hong Kong? International Journal on Disability and Human Development, 12(2), 115-125. https://doi.org/10.1515/ijdhd-2012-0139

Li, X., \& Pollatsek, A. (2011). Word Knowledge Influences Character Perception. Psychonomic Bulletin \& Review, 18(5), 833-839. https://doi.org/10.3758/s13423-011-0115-8

Luo, T. (2018). Delving into the Specificity of Instructional Guidance in Social Media-supported Learning Environments. Journal of Information Technology Education: Innovations in Practice, 17, 37-54. https://doi. org/10.28945/3974 
Mulyono, A. M. (2001). Aktivitas Belajar. Bandung: Yrama.

Omar, K. A., Omar, D., Othman, S., \& Yusoff, Z. M. (2017). The Influence of Physical Environment on the Character of Youths. Pertanika Journal of Social Sciences \& Humanities, 25(S), 35-42.

Prasetiyono, J. (2015). Upaya Guru Bimbingan dan Konseling Dalam Mengubah Persepsi Negatif Siswa Tentang Bimbingan dan Konseling di Madrasah Aliyah Negeri Buntok Kabupaten Barito Selatan. Guidance and Counseling, 1(1), 39-45.

Wilodati. (2016). Children's Character Development: A Father's Role. Man in India, 96(12), 5053-5069.

Yamamoto, Y., Shinozaki, T., Ikegami, Y., \& Tsuruta, S. (2016). Context Respectful Counseling Agent Virtualized on The Web. World Wide Web, 19(1), 111-134. https://doi.org/10.1007/s11280-015-0326-4 